\title{
Introduction to Proceedings of International Symposium "Migration and Colonization in the Mediterranean during the First Millennium BC"
}

\author{
Ronaldo G. Gurgel Pereira*
}

\begin{abstract}
PEREIRA, R. G. G. Introduction to Proceedings of International Symposium "Migration and Colonization in the Mediterranean during the First Millennium BC". R. Museu Arq. Etn., 33: 1-2, 2019.
\end{abstract}

T he European Union currently faces some sort of internal identity crisis, and beyond that, the identity of Europe and what obligations and responsibilities Europeans will have towards one another are also questioned. However, identity is not a problem that exists only at the European level; it exists in every State in Europe as well. The question of national identity was one that Europeans hoped to be able to avoid in the decades after World War II.

However, immigration and the growth of cultural diversity - or, the rise of the so feared "multiculturalism" - have turned identity into an issue that all must confront. The need to deal with the very concept of cultural identity implies the rearrangement of the past. It is fair to posit that the process by which societies put their past into perspective acts as a "mirror" able to make their present understandable, explicable, or even reasonable.

Negotiating identities (national, regional, linguistic, etc.) requires their redefinition and a reconsideration of certain conceptions, such as those of universality, nationality or citizenship. What one must bear in mind, however, is that the European project is based on the existence of an European people and not on the abolishment of national identities.

Moreover, given that identities are constructed and reconstructed through social action (as they are not static), multiculturalism seems to be the

* Researcher at Centro de Humanidades of Faculdade de Ciências Sociais e Humanas of Universidade Nova de Lisboa. <ronaldo.gurgel@yahoo.de> only solution to address the identity mosaic that characterizes European society. This concept allows for the existence of multiple national identities, without imposing one above the others, while aiming at reducing the potential for conflict, by building an overall sense of tolerance.

Thus, the research group "Antiquity and its Reception" (Centro de Humanidades da Faculdade de Ciências Sociais e Humanas/ Universidade Nova de Lisboa) hosted an international symposium on the theme "Migration and Colonization in the Mediterranean during the first Millennium BC". The symposium promoted a debate on approaches to study ancient people's mobility, migration, colonization and cross-cultural contacts across the Mediterranean basin.

The following six papers here presented promote a rich debate on the relations between "Us" vs. "Them" in different contexts of mobility, immigration and colonization. Their backgrounds include areas from the Eastern, Central and Western Mediterranean basin. Realities in focus comprise the updates into religious views in Israel, to the Phoenician and Greek establishment of new settlements in the West, and finally the Macedonian hegemony over Egypt at the end of the millennium.

The Mediterranean region includes twenty-five nations today, having witnessed the development of some of the most important cultures of the past, thanks to the ease of trade and cross-cultural exchanges afforded by the Mediterranean Sea. The concentration of 
port-cities around its coast reveals the ease with which cultures have been spread by this medium.

Thus, such "intercourse" includes not only material goods, but also modes of thought. Commercial ties allowed foreign affairs to be solved through diplomatic exchanges, whereas wars between kings and cities required the use of foreign mercenary armies.

Since the dawn of time, people and material culture travelled across the Mediterranean Sea. However, during the first millennium BC, the region witnessed an unprecedented movement of people in large migratory waves, establishing colonies overseas. The Mediterranean became a wide trade network, and the resources being explored, traded and consumed by the ancient Mediterranean societies encompassed human labor, metals, agricultural products, and processed goods. In addition, the Inner Sea also offered the means for cultural contacts and the transfer of knowledge and technologies.

The arrival of new colonial settlements and migrants also created areas of colonial encounters. Colonial relations shaped the interest in the travel of material culture and style across borders. Such interactions have often been used to debate the ethnic identity of the receiving culture.

During the First Millennium BC, the Mediterranean witnessed the increasing influx of peoples aiming to construct new settlements. As a result, the indigenous communities updated their own world perception by assimilating the "foreigner" as a natural social category. Consequently, we can ask some general questions:

What are the economic, social and cultural consequences for the development of colonial areas? How natives and foreigners interacted? How social hierarchies of "us" vs. "them" have been developed?

On the other hand, as new identities emerge, how to approach the conflicts between ethnic versus cultural identities? Plus, how aware a given group is of its own "new identity" as being "new" at all?

A comparative approach allowed the debate on different realities of migration and colonization, both in space as in time. This dossier shall be an interesting asset to those who need to compare bibliographies, sources, uses of concepts and opinions in order to put into perspective their own understandings of the same phenomenon.

Concluding with the proposition that all history is actually "contemporary history" seems fair, since individuals are always looking back to their past, searching for a link to their origins, for symbolic justifications to their civilization, and willing to protect their correlation with their ancestors and heritage.

To discuss history, to understand it, looks simpler when focusing on a case study from the remote past. However, humanity still feels the same eagerness to understand how to be best integrated with the past to extend the present idea of "continuity" to the future.

Historians cannot predict the future; however, the past they portray must be one out of which the present can plausibly have grown. Thus, the study of human history should transcend boundaries rather than reinforce or reproduce them. 


\title{
Introdução às Atas do Simpósio Internacional "Migration and Colonization in the Mediterranean during the first Millennium BC"
}

\author{
Ronaldo G. Gurgel Pereira*
}

\begin{abstract}
PEREIRA, R. G. G. Introdução às Atas do Simpósio Internacional "Migration and Colonization in the Mediterranean during the first Millennium BC". R. Museu Arq. Etn., 33: 1-2, 2019.
\end{abstract}

A tualmente ocorre uma espécie de crise de identidade no seio da União Europeia. Mais especificamente, uma crise relacionada à definição das obrigações e responsabilidades dos europeus para com a sua comunidade. Todavia, a questão da identidade não surge apenas quando nações confrontam a "identidade europeia". Ela também se faz presente dentro dos próprios estados-membros. Trata-se, porém, de uma questão delicada, uma vez que a "identidade nacional" se tornara uma espécie de tabu a ser evitado desde o fim da Segunda Guerra Mundial.

Contudo, essa questão retornou à pauta do dia graças ao crescente fluxo de imigrações de fora do espaço europeu e ao desenvolvimento do tão temido "multiculturalismo". Assim, a necessidade de discutir o próprio conceito de "identidade cultural" nos obriga a revisitar o passado e, por vezes, reinventá-lo. Pode-se afirmar que esse processo provoca o surgimento de novas perspectivas de passado, reinventado, para tornar o presente justificável, legítimo, ou mesmo verossímil.

O processo de negociação de identidades (seja em nível nacional, regional, linguístico, entre outros) requer a redefinição e a reconsideração de determinados conceitos, como o de universalidade, nacionalidade ou cidadania. Mas tenhamos em mente que o chamado "Projeto Europeu" é baseado na existência de um

* Investigador integrado do Centro de Humanidades da Faculdade de Ciências Sociais e Humanas da Universidade Nova de Lisboa. <ronaldo.gurgel@yahoo.de> "povo europeu", sem haver necessariamente a abolição das identidades nacionais.

Além disso, uma vez que as identidades são construídas e reconstruídas mediante a interação social (posto que identidades não são estáticas, mas dinâmicas), o multiculturalismo aparenta ser a estratégia viável para lidar com o mosaico identitário da sociedade europeia. Essa abordagem concebe a existência de múltiplas identidades nacionais sem a necessidade de hierarquizações. O mesmo conceito reduz o potencial para o conflito, pois edifica um senso de tolerância inclusivo.

Nesse contexto, o grupo de investigação "A Antiguidade e a sua Recepção" (Centro de Humanidades da Faculdade de Ciências Sociais e Humanas/Universidade Nova de Lisboa) realizou um evento internacional dedicado ao estudo da mobilidade de povos antigos pelo Mediterrâneo durante o I milênio a.C. O simpósio "Migration and Colonization in the Mediterranean during the first Millennium BC" debateu as abordagens teóricas e as questões metodológicas empregadas em estudos de caso sobre relações interculturais em diversos recortes espaciais e temporais.

Atualmente, 25 nações dividem a região do Mar Mediterrâneo. Esse espaço testemunhou o desenvolvimento de algumas das mais importantes culturas do passado, graças às facilidades de comércio e relações interculturais proporcionadas pelo mar. A concentração de cidades portuárias na sua costa comprova a intensidade e o vigor da expansão cultural dessas civilizações. 
Entenda-se que tal "intercurso" inclui tanto o influxo de cultura material como de visões de mundo e modos de pensamento.

Os laços comerciais permitiam que as relações internacionais desenvolvessem intercâmbios diplomáticos, enquanto as guerras entre cidades e reinos eram frequentemente resolvidas com o auxílio de exércitos mercenários estrangeiros.

O Mar Mediterrâneo é um espaço de circulação de povos, cultura material e ideias. Apesar de redes comerciais serem atestadas em períodos anteriores, foi a partir do I milênio a.C. que o fluxo de bens e pessoas se intensificou a ponto de conectar todo o mar numa só rede comercial.

Inicialmente, a exploração de recursos, as trocas e relações comerciais criaram um espaço para a transmissão de tecnologias e troca de conhecimentos e visões de mundo. Num segundo momento, esse ambiente propiciou também a fundação de assentamentos permanentes de populações estrangeiras, formando áreas de "encontros coloniais". Geralmente essas áreas de contato são exploradas pela arqueologia como forma de discutir questões de identidade étnica e/ou cultural a partir da cultura material importada ou produzida.

Tendo como base essa realidade de encontros entre povos, o nosso simpósio dedicou-se à seguinte problemática: quais são as consequências econômicas, sociais, culturais e religiosas para o desenvolvimento dessas áreas de contato? Como se desenvolveram as interações entre nativos e estrangeiros? Elas implicavam necessariamente o processo de hierarquização do "outro"?

A formação dessas áreas de contato diluem a linha que separa o "nós" do "eles". Seria também possivel identificar conflitos na relação de identidade étnica e identidade cultural de dado grupo? Seria possivel que dado grupo sofresse alterações em seu universo simbólico, sem se aperceber de estar a se transformar em algo "novo"?

O simpósio analisou diferentes realidades cronológicas e espaciais a partir de uma abordagem comparativa. Os estudos de caso aqui discutidos oferecem uma importante atualização bibliográfica e metodológica para aqueles que buscam desenvolver pesquisas similares. As seis contribuições selecionadas debatem relações entre estrangeiros e nativos, sob contextos de mobilidade, imigração e colonização. Os casos analisados espalham-se pelo Mediterrâneo oriental, central e ocidental, descrevendo realidades de encontros distintas cronologicamente, abrangendo desde o início do I milênio a.C., passando pelas navegações fenícias e gregas, até os últimos anos de hegemonia greco-macedônica no Egito.

Finalmente, podemos propor que todo o estudo da história é, por excelência, um estudo de "história contemporânea". O ser humano sempre olhou para trás, para o seu passado, buscando um elo com as suas origens e uma explicação para a sua própria razão de ser. As respostas que a humanidade encontra para esses questionamentos fornecem justificativas simbólicas para as suas respectivas civilizações, bem como protegem a correlação entre os vivos e os seus ancestrais, suas tradições e heranças culturais.

Discutir e compreender esse processo pode parecer mais simples quando se realiza um estudo de caso situado no passado remoto. Todavia, o homem ainda sente a mesma ansiedade por compreender como pode estar mais integrado com o próprio passado de modo a legitimar o seu presente, como uma ordeira e pacífica "continuidade" rumo ao futuro.

Não cabe aos historiadores a tarefa de prever o futuro. Porém, o passado que descrevemos deve ser isento de determinismos. Ele precisa ser contextualizado como uma mera opção - dentre muitas outras plausíveis - a partir da qual o presente tomou forma. Logo, o estudo da história humana deveria preocupar-se em transcender as fronteiras, em vez de reforçálas ou reproduzi-las. 